\title{
STRUCTURAL SYNTHESIS OF A STABILIZING ROBUST CONTROLLER OF THE ROTOR FLUX LINKAGE
}

Purpose. The aim is to structural synthesis of robust stabilizing control of the rotor flux vector control system of induction motor. Methodology. Synthesis controller structure was carried out in two stages. The first stage constructed a mathematical model of the channel of the rotor flux with parametric uncertainty and calculated transfer function of $H_{\infty}-$ suboptimal controller by method of the mixed sensitivity. The second stage was carried out the expansion of the transfer function of the continued fraction for the Euclidean algorithm. This fraction was used to construct the controller structural scheme. Results. Computer modeling of the transfer function of $H_{\infty}$-suboptimal controller. Achieved decomposition found the transfer function of the continued fraction. The flow diagram of suboptimal $\mathrm{H}_{\infty}$-controller with a proportional and integrating links and a few summers. The curves of transient rotor flux linkage in packages Robust Control Toolbox and Simulink. They coincide in the steady state, but differ among themselves in the transition. Originality. We developed the method of structural synthesis of robust stabilizing controller of the flux linkage rotor, $H_{\infty}-$ suboptimal structural scheme of which is presented in the form of simple compounds integrating and proportional elements of the same order as the controller with the strictly correct transfer function, and takes into account the parametric uncertainty of control object. The results of the simulation of transient processes in a variety of packages MATLAB applications confirms the adequacy and small sensitivity of the system to parametric perturbation. The practical value. The resulting structure of the controller makes it possible to carry out the modernization of electric control systems, in use, with minimal financial costs. References 10, figures 6.

Key words: electric drive, vector control, flux linkage channel, structure of $\boldsymbol{H}_{\infty}$-optimal controller.

Цель. Целью работы является структурный синтез стабилизирующего робастного регулятора потокосцепления ротора системы векторного управления асинхронного электропривода. Методология. Синтез структуры регулятора проводился в два этапа. На первом этапе строилась математическая модель канала потокосцепления ротора с параметрической неопределенностью и рассчитывалась передаточная функция Н субоптимального регулятора по методу смешанной чувствительности. На втором этапе выполнялось разложение найденной передаточной функции в цепную дробъ по алгоритму Евклида. Эта дробь использовалась для построения структурной схемы регулятора. Результаты. Проведено компьютерное моделирование передаточной функции Н

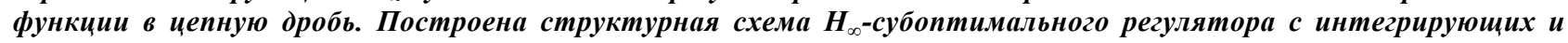
пропорциональных звеньев и нескольких сумматоров. Получены кривые переходных процессов потокосцепления pomopa в пакетаx Robust Control Toolbox и Simulink. Они совпадают на установившемся режиме, а на переходном несколько отличаются между собой. Новизна. Построена математическая модель канала потокосцепления ротора с параметрической неопределенностью. Разработана методика структурного синтеза робастного регулятора системы управления потокосцеплением, которая обеспечивает нахождение оптимальной передаточной функции регулятора с параметрической неопределенностью в виде структуры, содержащей интегрирующие и пропорциональные звенья и сумматоры. Практическое значение. Полученная структура регулятора дает возможность проводить модернизацию систем управления электроприводов, находящихся в эксплуатации, с минимальными финансовыми затратами. Библ. 10, рис. 6.

Ключевые слова: электропривод, векторное управление, канал потокосцепления, структура Н регулятора.

Introduction. Stricter quality requirements for the functioning of the vector control of induction electric drives in conditions of uncertainty leads to the need to stabilize the rotor flux. This is essential problem of structural synthesis of robust stabilizing controller. However, such a regulator is usually of higher order which makes it difficult to use the vector control system. Decomposition of robust regulator on the elementary units allows you to get rid of this shortcoming. Its essence is to control the representation of a structure consisting of standard units. To create a regulator of such links element base exists. Realization of control on the basis of this framework permits to stabilize the rotor flux linkage, as well as to modernize the control systems in use, with little financial cost.

The issues of stabilization of the parameters of vector control systems with uncertainties involved many researchers [1-6]. They built mathematical models and synthesized robust controls for many kinds of systems.

The goal of the work is structural synthesis of robust stabilizing control of the rotor flux vector control system of induction electric drive.

The theoretical basis for the structural synthesis of robust control knob served $H_{\infty}$-theory [7] and the theory of continued fractions [8]. Calculations were carried out with the assistance of MATLAB-7 expansion packs [9]. The studies were discussed at the VII International Scientific and Technical conference «Innovations in Shipbuilding and Ocean Engineering» (Ukraine, Nikolaev, 2016).

Methods and results of investigations. Fig. 1 is a block diagram of the channel of the rotor flux linkage in the space of signals «input-output» [10], which includes

(C) N.J. Khlopenko, I.N. Khlopenko 
the transfer functions of the frequency converter and the stator windings 1 and rotor windings 2 of induction motor with squirrel-cage rotor.

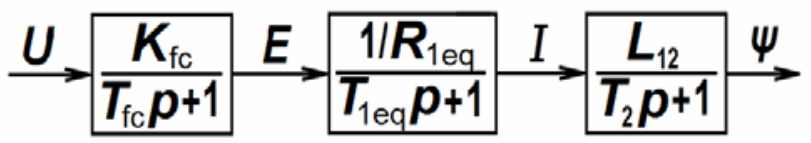

Fig. 1. A block diagram of the rotor flux linkage channel

In this scheme, the uncertainty of the parameters that are most sensitive to changes in the object model, the gain of the frequency converter have been chosen $K_{\mathrm{fc}}$, equivalent active resistances $R_{\text {leq }}$ and $R_{2}$, inductances $L_{1}$, $L_{2}$ and mutual inductance $L_{12}$ of stator winding 1 and rotor winding 2 , and $R_{1 \mathrm{eq}}=R_{1}+\left(k_{2}\right)^{2} R_{2} \quad\left(R_{1}\right.$ is the active resistance); $k_{2}=L_{12} / L_{2}$.

We proceed from the block diagram of the equations of state in the normal form of the operator:

$$
\begin{aligned}
& p E=-\frac{1}{T_{\mathrm{fc}}} E+\frac{K_{\mathrm{fc}}}{T_{\mathrm{fc}}} U ; \\
& p I=-\frac{1}{T_{1 \mathrm{eq}}} I+\frac{1}{R_{\text {leq }} T_{1 \mathrm{eq}}} E ; \\
& p \Psi=-\frac{1}{T_{2}} \Psi+\frac{L_{12}}{T_{2}} I,
\end{aligned}
$$

where $p$ is the Laplace operator; $E$ is the EMF of the frequency converter; $U$ is the control action (the projection of the stator voltage vector in the direction of the vector of the rotor flux linkage); $I$ is the current in the channel of the rotor flux linkage; $T_{\mathrm{fc}}$ is the time constant of the frequency converter; $T_{1 \mathrm{eq}}=L_{1 \mathrm{eq}} / R_{\text {leq }}$ is the electromagnetic stator winding time constant; $L_{1 \mathrm{eq}}=\sigma L_{1}$ is its equivalent inductance; $\Psi$ is the magnitude of the rotor flux linkage; $T_{2}=L_{2} / R_{2}$ is the rotor winding electromagnetic time constant; $\sigma=1-\left(L_{12}\right)^{2} /\left(L_{1} L_{2}\right)$ is the scattering coefficient of the magnetic field.

Coefficients $k_{2}$ and $\sigma$ are assumed constant. We introduce the dimensionless quantities

$$
x_{1}=\frac{\Psi}{\Psi_{\mathrm{n}}}, \quad x_{2}=\frac{I}{I_{\mathrm{n}}}, \quad x_{3}=\frac{E}{E_{\mathrm{n}}}, u=\frac{U}{U_{\mathrm{n}}},
$$

where $n$ is the index of nominal quantities.

We proceed in the equations (1) to dimensionless quantities (2):

$$
\begin{aligned}
& p x_{1}=-\frac{1}{T_{2}} x_{1}+\frac{L_{12} I_{\mathrm{n}}}{T_{2} \Psi_{\mathrm{n}}} x_{2} ; \\
& p x_{2}=-\frac{1}{T_{1 \mathrm{eq}}} x_{2}+\frac{E_{\mathrm{n}}}{R_{1 \mathrm{eq}} T_{1 \mathrm{eq}} I_{\mathrm{n}}} x_{3} ; \\
& p x_{3}=-\frac{1}{T_{\mathrm{fc}}} x_{3}+\frac{K_{\mathrm{fc}} U_{\mathrm{n}}}{T_{\mathrm{fc}} E_{\mathrm{n}}} u .
\end{aligned}
$$

Using equations (3), we construct a structural diagram of a system in the state space (Fig. 2).

We assume that undetermined system parameters $K_{\mathrm{fc}}, R_{1 \mathrm{eq}}, R_{2}, L_{1}, L_{2}$ and $L_{12}$ change in intervals

$$
\begin{aligned}
& K_{\mathrm{fc}}=K_{\mathrm{fc} \mathrm{n}}\left(1+p_{K_{\mathrm{fc}}} \delta_{K_{\mathrm{fc}}}\right) ; \\
& R_{1 \text { eq }}=R_{1 \text { eq } \mathrm{n}}\left(1+p_{R_{\text {leq }}} \delta_{R_{\text {leq }}}\right) ; \\
& R_{2}=R_{2 \mathrm{n}}\left(1+p_{R_{2}} \delta_{R_{2}}\right) ; \\
& L_{\text {leq }}=L_{1 \text { eq n }}\left(1+p_{L_{1 \mathrm{eq}}} \delta_{L_{\text {leq }}}\right) ; \\
& L_{2}=L_{2 \mathrm{n}}\left(1+p_{L_{2}} \delta_{L_{2}}\right) ; \\
& L_{12}=L_{12 \mathrm{n}}\left(1+p_{L_{12}} \delta_{L_{12}}\right) ;
\end{aligned}
$$

where $p_{K_{\mathrm{fc}}}, p_{R_{\text {leq }}}, p_{R_{2}}, p_{L_{\text {leq }}}, p_{L_{2}}, p_{L_{12}}$ are the relative values of the coefficients of variance of undetermined parameters $\delta_{K_{\mathrm{fc}}}, \delta_{R_{\mathrm{leq}}}, \delta_{R_{2}}, \delta_{L_{\mathrm{leq}}}$, $\delta_{L_{2}}$ and $\delta_{L_{12}}$.

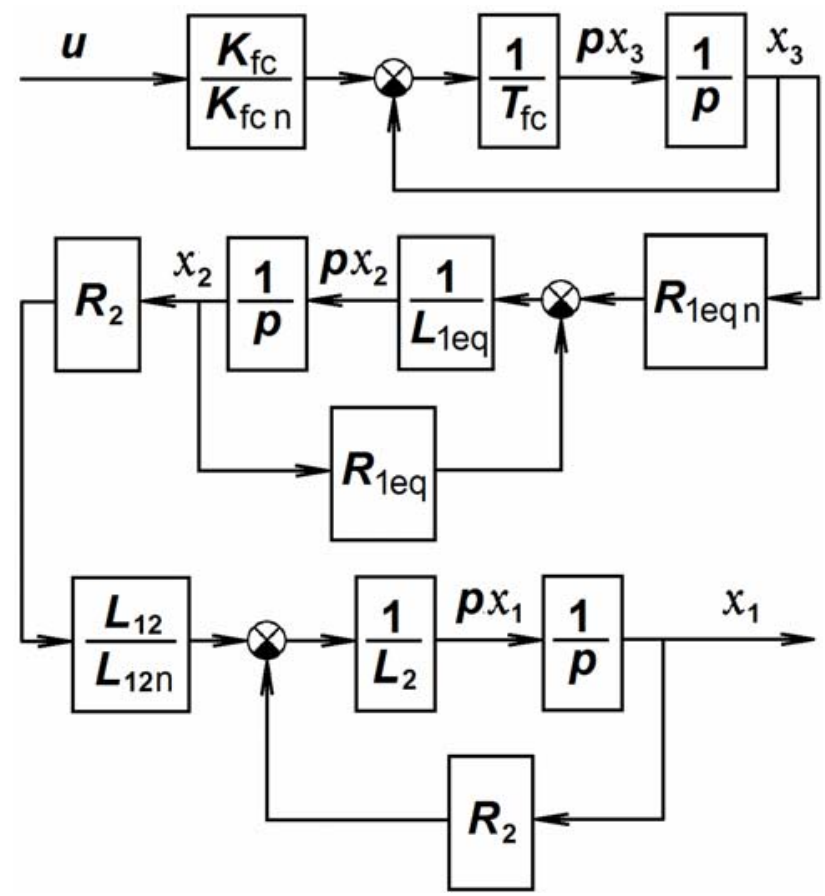

Fig. 2. A block diagram of the rotor flux linkage channel in the state space

We replace each of the parameters (4) shown in Fig. 2 a block diagram. The result is a structural diagram of a system with parametric uncertainty shown in Fig. 3.

We proceed from this block diagram to the vector equations of state in the operator form:

$$
\begin{aligned}
& p x=A x+B_{1} w+B_{2} u \\
& z=C_{1} x+D_{11} w+D_{12} u \\
& y=C_{2} x+D_{21} w+D_{22} u,
\end{aligned}
$$

where

$$
A=\left[\begin{array}{ccc}
-\frac{R_{2 \mathrm{n}}}{L_{2 \mathrm{n}}} & \frac{R_{2 \mathrm{n}}}{L_{2 \mathrm{n}}} & 0 \\
0 & -\frac{R_{1 \mathrm{eqn}}}{L_{\text {leq } \mathrm{n}}} & \frac{R_{\text {leq } \mathrm{n}}}{L_{\text {leq } \mathrm{n}}} \\
0 & 0 & -\frac{1}{T_{\mathrm{fc}}}
\end{array}\right] ;
$$




$$
B_{1}=\left[\begin{array}{ccccccc}
0 & 0 & 0 & \frac{p_{R_{2}}}{L_{2 \mathrm{n}}} & \frac{p_{L_{12}}}{L_{2 \mathrm{n}}} & 0 & -\frac{p_{R_{2}}}{L_{2 \mathrm{n}}} \\
0 & -p_{L_{\text {leq }}} & -\frac{p_{R_{\text {leq }}}}{L_{\text {leqn }}} & 0 & 0 & 0 & 0 \\
\frac{p_{K_{\mathrm{fc}}}}{T_{\mathrm{fc}}} & 0 & 0 & 0 & 0 & 0 & 0
\end{array}\right] ;
$$$$
C_{1}=\left[\begin{array}{ccc}
0 & 0 & 0 \\
0 & -\frac{R_{\text {leqn }}}{L_{\text {leqn }}} & \frac{R_{\text {leqn }}}{L_{\text {leqn }}} \\
0 & R_{1 \text { eqn }} & 0 \\
0 & R_{2 \mathrm{n}} & 0 \\
0 & R_{2 \mathrm{n}} & 0 \\
-\frac{R_{2 \mathrm{n}}}{L_{2 \mathrm{n}}} & \frac{R_{2 \mathrm{n}}}{L_{2 \mathrm{n}}} & 0 \\
R_{2 \mathrm{n}} & 0 & 0
\end{array}\right] ; C_{2}=\left[\begin{array}{lll}
1 & 0 & 0
\end{array}\right] ;
$$$$
D_{11}=\left[\begin{array}{ccccccc}
0 & 0 & 0 & 0 & 0 & 0 & 0 \\
0 & -p_{L_{\text {leq }}} & -\frac{p_{R_{\text {leq }}}}{L_{\text {leqn }}} & 0 & 0 & 0 & 0 \\
0 & 0 & 0 & 0 & 0 & 0 & 0 \\
0 & 0 & 0 & 0 & 0 & 0 & 0 \\
0 & 0 & 0 & p_{R_{2}} & 0 & 0 & 0 \\
0 & 0 & 0 & \frac{p_{R_{2}}}{L_{2 \mathrm{n}}} & \frac{p_{L_{12}}}{L_{2 \mathrm{n}}} & 0 & -\frac{p_{R_{2}}}{L_{2 \mathrm{n}}} \\
0 & 0 & 0 & 0 & 0 & 0 & 0
\end{array}\right] ;
$$$$
B_{2}^{T}=\left[\begin{array}{lll}
0 & 0 & \frac{1}{\mathrm{~T}_{\mathrm{fc}}}
\end{array}\right] ; D_{12}^{T}=\left[\begin{array}{lllllll}
1 & 0 & 0 & 0 & 0 & 0 & 0
\end{array}\right] ;
$$$$
D_{21}=\left[\begin{array}{lllllll}
0 & 0 & 0 & 0 & 0 & 0 & 0
\end{array}\right] ; D_{22}=[0] ;
$$

$x=\left(x_{1}, x_{2}, x_{3}\right)^{T}$ is the phase vector; $y$ is the $1 \mathrm{D}$ output vector by which closes feedback ; $z=\left(z_{1}, z_{2}, \ldots, z_{7}\right)^{T}$, $w=\left(w_{1}, w_{2}, \ldots, w_{7}\right)^{T}$ are the respectively the input and output vectors of uncertainty shown in Fig. 3.

The obtained equation (5) corresponds to the transfer function matrix $P(p)$, which is the standard form has the form (6):

$$
P(p)=\left[\begin{array}{ccc}
A & B_{1} & B_{2} \\
C_{1} & D_{11} & D_{12} \\
C_{2} & D_{21} & D_{22}
\end{array}\right] .
$$

It contains known and does not contain elements of uncertainty.

The matrix transfer function containing the uncertainty of the form (7):

$$
\Delta(p)=\left[\begin{array}{ccccccc}
\delta_{K_{\mathrm{fc}}} & 0 & 0 & 0 & 0 & 0 & 0 \\
0 & \delta_{L_{\mathrm{leq}}} & 0 & 0 & 0 & 0 & 0 \\
0 & 0 & \delta_{R_{\text {leq }}} & 0 & 0 & 0 & 0 \\
0 & 0 & 0 & \delta_{R_{2}} & 0 & 0 & 0 \\
0 & 0 & 0 & 0 & \delta_{L_{12}} & 0 & 0 \\
0 & 0 & 0 & 0 & 0 & \delta_{L_{2}} & 0 \\
0 & 0 & 0 & 0 & 0 & 0 & \delta_{R_{2}}
\end{array}\right] .
$$

It defines the relationship of the vector $w(p)$ with the vector $z(p)$.This relationship is described by the expression of matrix $w(p)=\Delta(p) \cdot z(p)$ which displays the system of equations (8):

$$
\begin{gathered}
w_{1}=\delta_{K_{\mathrm{fc}}} z_{1} ; w_{2}=\delta_{L_{\mathrm{leq}}} z_{2} ; \\
w_{3}=\delta_{R_{\mathrm{leq}}} z_{3} ; w_{4}=\delta_{R_{2}} z_{4} ; \\
w_{5}=\delta_{L_{12}} z_{5} ; w_{6}=\delta_{L_{2}} z_{6} ; w_{7}=\delta_{R_{2}} z_{7} .
\end{gathered}
$$

This system of equations is obtained by Fig. 3 .
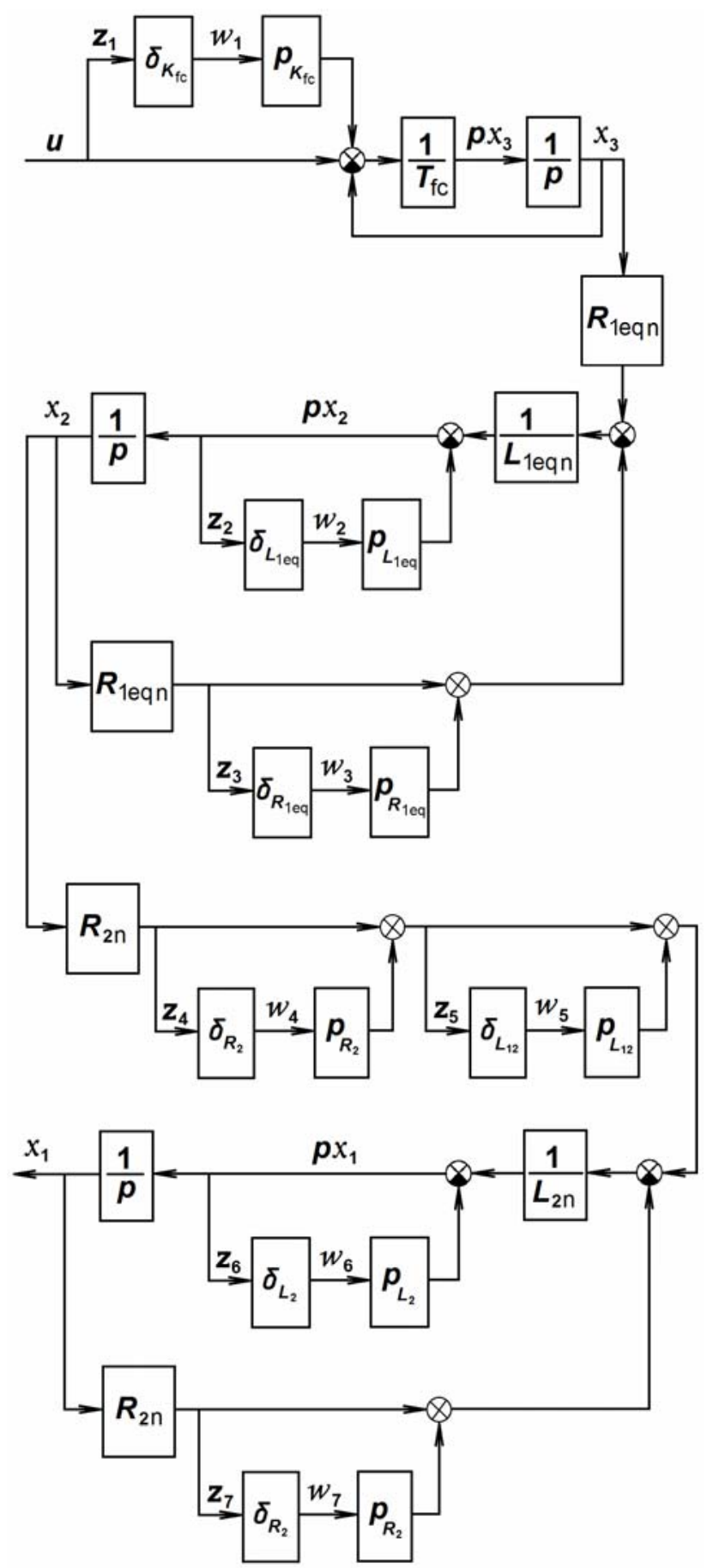

Fig. 3. A block diagram of the rotor flux linkage channel with undetermined parameters

Thus, a mathematical model of the channel of the rotor flux linkage in the space of states with parametric uncertainty is built.

Synthesis of optimal stabilizing $K(p)$ control was conducted by a mixed sensitivity for the object $P(p)$ the uncertainty $\Delta(p)$. 
The block diagram of the object $P(p)$ with uncertainty $\Delta(p)$ and the controller $K(p)$ is presented in Fig. 4.

The numerical solution was carried out at the following values of the original data with $T_{\mathrm{fc}}=0.001 \mathrm{~s}$; $R_{1 \mathrm{n}}=2.65 \Omega ; R_{2 \mathrm{n}}=2.0 \Omega ; L_{1 \mathrm{n}}=0.186 \mathrm{H} ; L_{2 \mathrm{n}}=0.189 \mathrm{H}$; $L_{12 \mathrm{n}}=0.179 \mathrm{H} ; \sigma=0.0996$ corresponding to the induction electric drive with motor MDXMA100-32.

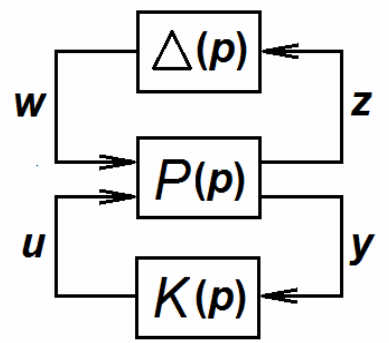

Fig. 4. The block diagram of the object $P(p)$ with uncertainty $\Delta(p)$ and the controller $K(p)$

Quality controlled system by means of three weighting functions [9] attached to the object $P(p)$. In the process of solving the mathematical model of $H_{\infty}{ }^{-}$ suboptimal robust controller is obtained. Its strippeddown strictly proper transfer function $K(p)$ (at a frequency of $\omega_{\mathrm{c}}=46.6 \mathrm{rad} / \mathrm{s}$ of one of the weighting functions [9]) has the form

$$
\frac{5.016 \cdot 10^{5}\left(p^{2}+148.963 p+1.0612 \cdot 10^{4}\right)}{p^{3}+1.451 \cdot 10^{4} p^{2}+1.262 \cdot 10^{7} p+3.532 \cdot 10^{7}} .
$$

Using the algorithm of the ancient Greek mathematician Euclid, we expand the transfer function (9) in the continued fraction [8]:

$$
\frac{5.016 \cdot 10^{5}}{\frac{1}{\frac{0.6963}{10^{4}}+\frac{1}{-19.7 p+\frac{0.5709}{10^{4}}+\frac{1}{1256 p+\frac{1}{r}}}}},
$$

where $r=0.2879 \cdot 10^{-3}$.

Structural circuit of the regulator corresponding fraction (10) is shown in Fig. 5. It consists of three integrating and four proportional units.

Fig. 6 shows curves (solid lines) obtained by simulating transient rotor flux linkage in the Robust Control Toolbox (Fig. 6,a) and the Simulink (Fig. 6,b) packages with a single step change reference variable, and the curve in Fig. 6,b is constructed with the assistance of the controller block diagram shown in Fig. 5. As expected, the two curves are identical at steady state. In transition mode, they are slightly different from each other in character and speed the flow of transients and overshoot are about $25 \%$. This overshoot is easily eliminated by the aperiodic links with transfer function $1 /(0.32 p+1)$ on the right side of the setting unit setting signal (dashed line in Fig. 6,b).

Similar calculations were carried out with various combinations of increased or reduced in 2 times uncertain parameters. Here, transient deviations from nominal curves were not observed.

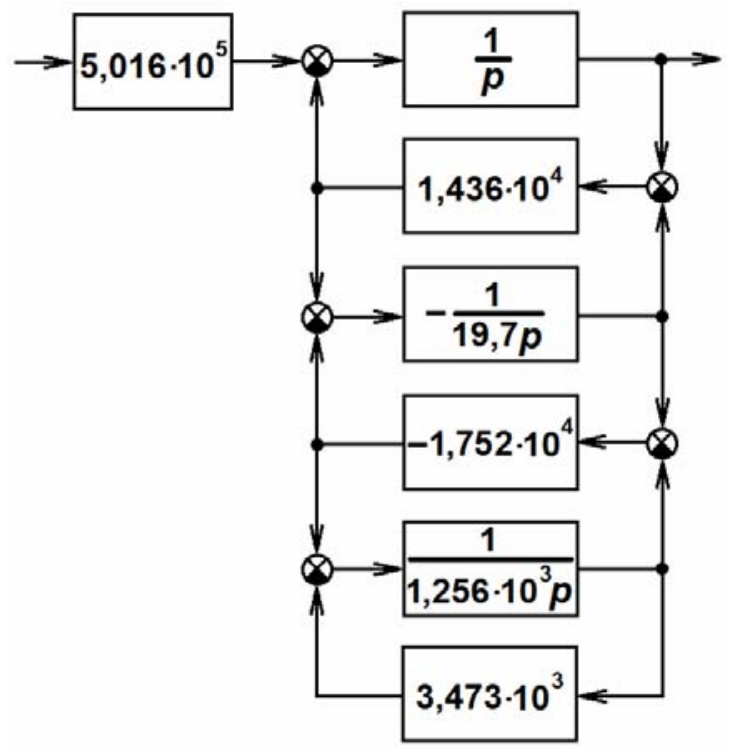

Fig. 5. Structural circuit of the $H_{\infty}$-suboptimal stabilizing robust controller
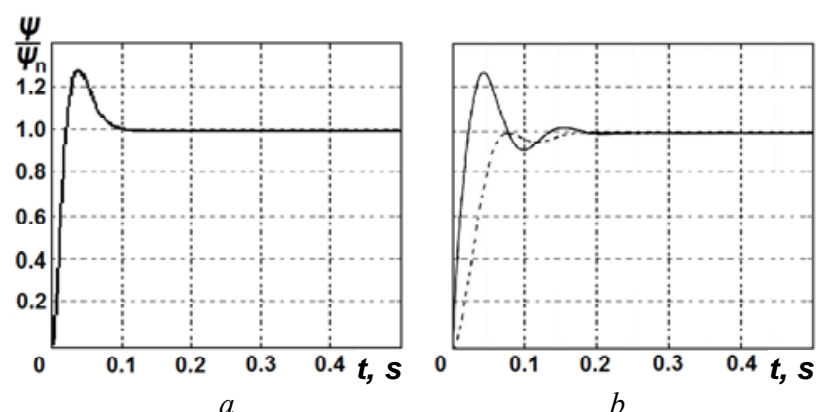

Fig. 6. Transients of the rotor flux linkage in packages Robust Control Toolbox $(a)$ and Simulink $(b)$ : the dotted line - overshoot $0 \%$; solid line $-25 \%$

\section{Conclusions.}

The technique of structural synthesis of robust stabilizing control regulator of the rotor flux linkage is proposed, $H_{\infty}$-suboptimal block diagram of which is presented in the form of connections of easily integrated and proportional parts of the same order as the regulator with a strictly proper transfer function, and takes into account the parametric uncertainty of the control object.

The results of the simulation of transient processes in a variety of packages MATLAB confirm the adequacy and small sensitivity of the system to parametric perturbations.

\section{REFERENCES}

1. Kuznetsov B.I., Nikitina T.B., Kolomiets V.V., Khomenko $\mathrm{V} . \mathrm{V}$. Investigation of the effect of nonlinearities and variations of the control object parameters on dynamic characteristics of the electromechanical servo systems. Bulletin of NTU «KhPI», 2015, no.12(1121), pp. 68-71. (Rus).

2. Kuznetsov A.P., Markov A.V. Shmarlevsky A.S. Analysis of channel settings control the rotor flux vector control system. Doklady BGUIR, 2008, no.4(34), pp. 84-91. (Belarus).

3. Nesenchuk A.A., Opeiko O.F., Odnolko D.S. Dynamics simulation and calculation of robust parameters for the electric 
drive control system on the basis of the root locus portraits. Artificial Intelligence, 2014, no.3, pp. 90-103. (Rus).

4. Peresada S.M., Kovbasa S.N., Bovkunovich V.S. Rough vector control torque and flux induction motor. Tekhnichna elektrodynamika, 2010, no.1. pp. 60-66. (Ukr).

5. Polilov E.V., Rudnev E.S., Skorik S.P. Synthesis of robust control algorithms for a synchronous electric motor means $H_{\infty}$ theory. Transactions of Kremenchuk Mykhaylo Ostrogradskiy State University, 2010, iss.4/2010(63), part 3, pp. 15-20. (Ukr). 6. Shiyka A.A., Potapenko E.M. Robust control of asynchronous electric minimizing power loss in real time. Bulletin of NTU «KhPI», 2013, no.36(1009), pp. 106-109. (Rus). 7. Egupov N.D. Metody robastnogo, neiro-nechetkogo $i$ adaptivnogo upravleniia [Methods of robust, neuro-fuzzy and adaptive control]. Moscow, Publishing House of the MSTU named after N.E. Bauman, 2002. 744 p. (Rus).

8. Khinchin D.Y. Tsepnye drobi [Continued fractions]. Moscow, Nauka Publ., 1978. 112 p. (Rus).

9. Richard Y., Chiang R., Michael G., Safonov M. MATLAB. Robust Control Toolbox. User's Guide. Version 2, 1998. 230 p.
Available at: http://www.mathworks.com (Accessed 12 May 2016).

10. Terekhov V.M., Osipov O.I. Sistemy upravleniia elektroprivodov: uchebnik dlia studentov vysshikh uchebnykh zavedenii [Control systems of electric drives: textbook for students of higher educational institutions]. Moscow, Akademiia Publ., 2006. 304 p. (Rus).

Received 21.10.2016

N.J. Khlopenko ${ }^{1}$, Doctor of Technical Science, Professor,

I.N. Khlopenko ${ }^{1}$, Master of Science,

${ }^{1}$ Admiral Makarov National University of Shipbuilding, 3, Central Ave., Nikolaev, 54021, Ukraine, phone +380512 709100,

e-mail: ivan.hlopenko@yandex.ua

How to cite this article:

Khlopenko N.J., Khlopenko I.N. Structural synthesis of a stabilizing robust controller of the rotor flux linkage. Electrical engineering \& electromechanics, 2017, no.1, pp. 21-25. doi: 10.20998/2074-272X.2017.1.04. 